\author{
ROMUALD CUDAK \\ (D) https://orcid.org/0000-0001-6047-680X \\ Uniwersytet Śląski w Katowicach \\ Katowice
}

\title{
Glottodydaktyka polonistyczna w perspektywie przemian
}

\author{
Glottodidactics in Polish studies in \\ view of transformations
}

\begin{abstract}
The paper reflects on the development and the transformations which contemporary Polish glottodidactics faces and must somehow address in the coming years. The first part contains a discussion of W. Miodunka's book on the creation, current status and developmental prospects of Polish glottodidactics, as well as a description of a collective work on teaching Polish as a foreign language in light of the prospects for development of education in the field of Polish studies. The second part discusses the need for glottodidactics to take a position on the turnabout taking place in the humanities as well as on the environmental crisis, migration and the pandemic.
\end{abstract}

Keywords: glottodidactics in Polish studies, new humanities, environmental crisis, migration, pandemic

Celem niniejszego artykułu jest przyjrzenie się przemianom, przed jakimi staje współczesna glottodydaktyka polonistyczna i wobec których musi się jakoś opowiedzieć w ciagu następnych lat. Część z nich to sytuacje w pewnej mierze już przez nią rozpoznane, przeobrażenia, które już się dokonują (dokonały) w obrębie refleksji naukowej i praktyki dydaktycznej. Część czeka na reakcję z jej strony. Przywilejem takich dyscyplin, jak dydaktyka szkolna czy glottodydaktyka jest to, że nie muszą reagować na możliwości przemian natychmiast, kiedy jeszcze trwa rebelia, która je wytwarza. Kiedy jednak formuje się krajobraz po bitwie, pora i im ustosunkować się wobec zaistniałych nowych spojrzeń i wizji. 
W ostatnich pięciu latach na rynku wydawniczym ukazały się dwie książki niezwykle cenne dla edukacji polonistycznej cudzoziemców. Pierwsza z nich to Glottodydaktyka polonistyczna. Pochodzenie - stan obecny - perspektymy wydana w 2016 roku przez oficynę Księgarnia Akademicka. Jej autorem jest Władysław T. Miodunka, jeden z pionierów nauczania języka polskiego wśród cudzoziemców, osoba niezwykle zaangażowana i zasłużona dla glottodydaktyki polonistycznej, guru w tej dziedzinie. Druga praca to dzieło zbiorowe zatytułowane Nauczanie i promocja jezyka polskiego w świecie. Diagnoza - stan perspektywy i wydane przez Wydawnictwo Uniwersytetu Śląskiego w Katowicach w 2018 roku. Zespół autorski pracujący pod przewodem Władysława T. Miodunki i Jolanty Tambor liczył czternaście osób. Są to znani badacze zajmujący się problematyką edukacji polonistycznej w świecie i aktywni dydaktycy w tym zakresie z różnych środowisk uniwersyteckich: Aleksandra Achtelik, Romuald Cudak, Danuta Krzyżyk, Jan Mazur, Bernadeta Niesporek-Szamburska, Kazimierz Ożóg, Adam Pawłowski, Dorota Praszałowicz, Anna Seretny, Roman Szul, Agnieszka Tambor, Tadeusz Zgółka1. Fakt, że obie monografie są solidnymi kompendiami z zakresu nauczania języka polskiego jako obcego i zawierają obszerne rozdziały poświęcone perspektywom (rozwojowi) glottodydaktyki, zobowiązuje, aby - postulatywne w swojej istocie - refleksje dotyczące przemian edukacji polonistycznej wśród cudzoziemców zacząć właśnie od przypomnienia tych prac.

Glottodydaktyka polonistyczna W.T. Miodunki jest w istocie podsumowaniem dotychczasowego dorobku naukowego tej dyscypliny. Praca składa się z sześciu rozdziałów. Początkowy ukazuje rozwój naukowej refleksji nad nauczaniem języka polskiego jako obcego. To, zdaniem badacza, działania zapoczątkowane w drugiej połowie XX wieku przez polonistów Uniwersytetu Warszawskiego, kontynuowane następnie w innych ośrodkach uniwersyteckich wraz z rozwojem nauczania jezzyka polskiego jako obcego poza jego pierwszymi środowiskami. W tym rozdziale została sformułowana, co dla nas szczególnie ważne, definicja glottodydaktyki polonistycznej, do której trzeba będzie powrócić. Rozdziały kolejne rejestrują dorobek naukowy krajowej glottodydaktyki polonistycznej w zakresie metodyki nauczania języka

1 Zob. rzeczowe opracowania na temat obu publikacji: Gębal 2018; Tambor A. 2018; Zarzycka 2017; Zarzycka 2019. 
polskiego oraz towarzyszących jej, tworzących się, subdyscyplin. Miodunka omawia tu podręczniki z metodyki nauczania języka polskiego jako obcego, programy nauczania, poradniki metodyczne, prace stanowiące wkład do glottodydaktyki ogólnej. Już tutaj, jako że opis ma charakter ujęcia całościowego, odnotowane są prace poświęcone nauczaniu polszczyzny nie tylko jako języka obcego, ale także drugiego i odziedziczonego. Warto zwrócić uwagę, że omówione zostały również programy i opracowania książkowe dotyczące nauczania realiów i kultury polskiej jako obcej. W przypadku subdyscyplin zarysowany został, co oczywiste, stan początkowy, „wyjściowy”.

Rozwój glottodydaktyki polonistycznej jest widziany przez Autora z punktu widzenia innowacji. To swoiste „przemodelowanie” stanu obecnego z perspektywy „statycznej” na „dynamiczną” staje się widoczne w rozdziale czwartym. Umożliwia ono prezentację metodyki nauczania z perspektywy terminus ad quem i wpisanie refleksji nad językiem (i jego nauczaniem) drugim i odziedziczonym. Innowacyjność spojrzenia umożliwia jednocześnie zarysowanie ewolucji nauczania związanej z przejściem od językoznawczego modelu języka jako struktury (gramatyki) do języka jako narzędzia komunikacji i adaptowania do glottodydaktyki podejścia komunikacyjnego. Rozważania kończą się rozdziałem kolejnym, który jest propozycją periodyzacji dziejów glottodydaktyki polonistycznej. Jak w całej pracy, swoją koncepcję periodyzacji Miodunka nakreśla w kontekście innych wcześniejszych opracowań dotyczących tego zagadnienia.

Część postulatywna zamyka się w ostatnim, szóstym rozdziale. Omawiając perspektywy rozwoju glottodydaktyki polonistycznej, Autor wskazuje „mocne i słabe" strony dyscypliny w jej obecnym kształcie, rysuje perspektywy rozwoju badań naukowych w tym zakresie oraz rozwoju nauczania i uczenia się języka polskiego jako obcego/drugiego. Wiele miejsca poświęca również konieczności tworzenia wspólnoty dyskursywnej (termin G. Zarzyckiej) glottodydaktyków polonistycznych.

Niepodważalną wartością monografii Miodunki jest to, że stanowi ona dokumentację dorobku dość młodej, a okrzepłej już dyscypliny naukowejglottodydaktyki polonistycznej. Ważny jest także fakt, że Autor potrafi przekonująco udowodnić, iż prezentowane w książce badania można ująć w kategoriach specyficznej dyscypliny naukowej i de facto ogłosić formalnie (za)istnienie jej w nauce polskiej. Do zasług trzeba wreszcie dopisać i to, że Autor proponuje definicję tej dyscypliny, uznając proklamowaną oficjalnie naukę jako konkretną realizację szczegółowej odmiany glottodydaktyki ogólnej. Ta definicja, uwzględniająca odmienność tradycji nauczania języka polskiego jako obcego oraz specyfikę tego nauczania, brzmi następująco: 
Glottodydaktyka polonistyczna jest dziedzina nauk humanistycznych zajmująca się badaniem procesu nauczania i uczenia się polszczyzny jako języka obcego i drugiego. Przekonanie o powiązaniu i wzajemnej determinacji procesów nauczania i uczenia się powinno prowadzić do podniesienia efektywności obu procesów w wyniku wykorzystania ogólnej wiedzy glottodydaktycznej.

Glottodydaktyka polonistyczna zajmuje się m.in. metodyką nauczania języka polskiego jako obcego i drugiego, uważaną teraz za jedną z subdyscyplin glottodydaktyki, do których zaliczamy też: pedeutologię polonistyczną, akwizycję języka polskiego jako obcego i drugiego, polonistyczne językoznawstwo dydaktyczne, preparację i ewaluację materiałów glottodydaktycznych, nauczanie i uczenie się języka polskiego jako obcego i drugiego wspomagane komputerowo, sytuację polonistyki i nauczania języka polskiego jako obcego w poszczególnych krajach i regionach świata, politykę językową w zakresie promocji i nauczania polszczyzny w świecie, historię nauczania języka polskiego jako obcego i drugiego oraz glottodydaktykę porównawczą (Miodunka 2016, 54).

Przyjrzyjmy się bliżej proponowanej definicji, ponieważ wydaje się, że sankcjonuje użycie tego terminu, kiedy za zakres przedmiotowy uznamy cała współczesną refleksję naukową nad nauczaniem polonistycznym w świecie i częściowo w kraju oraz specyficzne krajowe i zagraniczne sytuacje dydaktyczne, które stanowią przedmiot tej refleksji.

W powszechnym rozumieniu glottodydaktyka jest terminem oznaczającym naukę i praktykę związaną z nauczaniem języków obcych w opozycji do dydaktyki nauczania języka rodzimego (ojczystego); glottodydaktyka w podstawowym rozumieniu to zatem nauczanie języków obcych i termin obywa się w tym przypadku bez dodatkowych dookreśleń, dopóki nie wskazujemy o jaką konkretną glottodydaktykę chodzi (np. glottodydaktyka języka angielskiego). W znaczeniu terminu zwykło używać się także pojęcia ,języka jako obcego", wyjaśniając termin glottodydaktyka nie tyle jako nauczanie języków obcych, ale jako nauczanie języków jako obcych (i odpowiednio: nauka o nauczaniu języków jako obcych), co pozwala nam użyć pojęcia w odniesieniu do języka rodzimego, w naszym przypadku - polskiego (glottodydaktyka języka polskiego jako obcego), wyuczanego właśnie jako obcego. Oba wyrażenia zakładaja, że uczącym się danego języka jest cudzoziemiec, dla którego poznawany język nie jest rodzimy, ale obcy. W tym ujęciu glottodydaktyka polonistyczna (a może precyzyjniej: glottodydaktyka języka polskiego) oznacza nauczanie języka polskiego jako obcego, nierodzimego, a więc przede wszystkim proces nauczania polszczyzny wśród cudzoziemców. 
Wprowadzenie w obszar definiowania sytuacji języka polskiego jako drugiego to znacząca innowacja Miodunki, ważna, ale wysuwająca chyba tak rozumianą naukę z tradycyjnych ram klasyfikacji i specyfikacji oraz sytuująca ją jako pogranicze tradycyjnej glottodydaktyki i dydaktyki języka polskiego. Myśl to godna zaakceptowania, bo uwzględniająca realne kłopoty ostrego wydzielania opozycji rodzimy - obcy w przypadku języka polskiego użytkowanego choćby w rozległej i zróżnicowanej diasporze polonijnej. Wydaje się, że jest to decyzja słuszna i ważna dla procesu nauczania, z nim bowiem wiążą się właśnie sytuacje edukacji językowej wśród osób starszych i młodzieży, dla których język polski nie jest obcy w sensie pochodzenia uczącego się (jest w jakiś sposób rodzimy), jednakże użytkowany słabo, inaczej lub po prostu nieużytkowany (także) ze względu na ograniczone kompetencje i sytuację zamieszkania. Otwarta w definicji Miodunki możliwość dalszego precyzowania przedmiotu badań i nauczania umożliwia dookreślanie zakresu przedmiotowego i włączenie weń np. sytuacji języka polskiego jako odziedziczonego. Takie ujęcie pozwala na kognitywne rozumienie definicji, w której kryterium zamkniętej klasy jest zastąpione „,podobieństwem rodzinnym” i implikuje jako właściwość transdyscyplinarne cechy definiowanych obiektów, a w praktyce integrację badań i praktyk.

Druga sprawa to pojawiające się wyrażenie „polonistyczna” zamiast „glottodydaktyka języka polskiego”. Jest to zapewne sprawa stylistyki, ale chciałbym użycie tego terminu spożytkować, pewnie zgodnie $z$ intencją jego twórcy, jeszcze inaczej. Z definicji wynika bowiem, że trzonem teorii i praktyki tej nauki jest nauczanie języka. Z pracy (i innych prac Autora, twórcy m.in. pojęcia kompetencji socjokulturowej ${ }^{2}$ ) wynika bowiem, że oczywiste jest przeświadczenie, iż język jest (fundamentalnym) fenomenem kulturowym i jego osadzenie w kulturze jest widoczne faktycznie na każdym piętrze organizacji wypowiedzi językowej. Nauczając języka, uczymy zatem jednocześnie kultury, w jakiej funkcjonuje. Przeświadczenie to jest również widoczne we fragmentach poświęconych omówieniu dorobku naukowego glottodydaktyki polonistycznej, gdzie przedmiotem analizy staje się nauczanie kultury (fragment 2.4. książi) ${ }^{3}$. Rzecz jednak w tym, iż warto byłoby przemyśleć,

2 Zob. Miodunka 2004.

3 Wydaje się, że aktualnie nauczanie kultury polskiej wśród cudzoziemców jest już osobna dyscypliną glottodydaktyczną rozwijaną w środowisku warszawskim (P. Garncarek i zespół z nim współpracujący), łódzkim (G. Zarzycka, twórczyni pojęcia lingwakultura), wrocławskim (U. Burzyńska) czy katowickim (A. Achtelik). Zob. także Baran 2015. Warto dodać, że rozwinięte są prace poświęcone nauczaniu literatury (R. Cudak, W. Próchniak) i filmu wśród cu- 
czy można zbliżyć glottodydaktykę polonistyczną w jej programowo-postulatywnym (innowacyjnym) charakterze do tego, co gdzie indziej nazywamy edukacja polonistyczna, zakładając, że proces nauczania dotyczy również w sposób świadomy zaprojektowanej edukacji kulturowej. To ważne, bo wiąże silniej glottodydaktykę w swej interdyscyplinarności nie tylko z glottodydaktyka ogólną i językoznawstwem, ale także z nowocześnie, szeroko rozumianą polonistyka. Narusza to na swój sposób intencje ukryte w etymologii nazwy (glotto- < glossa $=$ język, glottodydaktyka jako dydaktyka języka), aczkolwiek przecież już nie do końca podstawowe użycie terminu, bo glotto- wiąże się z obcościa ale trzeba skonstatować, że ta innowacja idzie z duchem czasu współczesnej i nowoczesnej dydaktyki oraz tendencji dążącej do integracji.

$$
* * *
$$

Druga z przywołanych książek przynosi spojrzenie na nauczanie języka polskiego jako obcego z perspektywy zinstytucjonalizowanej praktyki dydaktycznej i użytkowania języka w przestrzeni komunikacji szkolnej i pozaszkolnej. Jest kompendium wiedzy o obecności języka polskiego w świecie w zakresie nauczania i użytkowania widzianego z perspektywy promocji, zwłaszcza w obszarze środowiska biznesowego. Praca powstała jako wynik zapotrzebowania na opracowanie, które pomogłoby prowadzić aktywną i efektywną promocję języka polskiego przez agendy państwowe. Zasadniczym przedmiotem opracowania jest nauczanie języka polskiego w świecie jako obcego, drugiego, odziedziczonego, a po części rodzimego, ale prowadzone poza krajem. Obszarem naukowej penetracji są więc społeczne szkoły uzupełniające działające z inicjatywy polskich migrantów, lektoraty języka polskiego oferowane w kraju i na zagranicznych uniwersytetach, szkoły publiczne z językiem polskim w miejscach, gdzie istnieją duże skupiska polskiej diaspory oraz tzw. punkty konsultacyjne. Uczącymi się są zatem cudzoziemcy podejmujący naukę języka polskiego z różnych powodów, ale także dzieci migrantów europejskich, imigrantów i uchodźców osiadłych w Polsce, starsi i młodsi emigranci polonijni, dla których jest to język odziedziczony lub drugi, a także dzieci polskich emigrantów powracających do Polski, które narodziły się lub wychowywały poza granicami kraju.

dzoziemców (A. Tambor, M. Jelonkiewicz). Stowarzyszenie „Bristol” powołało odpowiednie sekcje, w których pracuje się nad nauczaniem w tych obszarach. 
Praca składa się z trzynastu rozdziałów, większość dotyczy nauczania języka polskiego w świecie. W przypadku nauczania rozdziały poświęcono lektoratom języka polskiego w Polsce i w zagranicznych ośrodkach akademickich, zwracając szczególną uwagę na sytuację studentów zagranicznych w Polsce, problemy lektoratów i polonistyk zagranicznych oraz certyfikacji znajomości języka polskiego jako obcego. W omówieniu szkolnictwa podjęto zagadnienia sytuacji językowej dzieci z rodzin polskich w kontekście migracji, kwestię placówek prowadzących nauczanie języka polskiego za granica, wyodrębniając oświatę polonijną na Wschodzie, sytuacji finansowej i prawnej oświaty polskojęzycznej, jak również kształcenia dzieci i młodzieży z kontekstem migracyjnym w polskim systemie edukacji. Osobne rozdziały poświęcono promocji języka polskiego i działaniom na rzecz jego statusu, roli technologii cyfrowych $\mathrm{w}$ tej promocji oraz literaturze polskiej jako narzędziu i przedmiotowi edukacji językowo-kulturowej. Rozdziały zostały zaopatrzone w streszczenia i końcowe podsumowania, a także postulaty i propozycje kierunków przyszłych działań. W ten sposób zarysowano również możliwości i kierunki rozwoju edukacji polonistycznej w świecie.

$* * *$

Założone funkcje obu przywołanych opracowań (powołanie i opis glottodydaktyki polonistycznej, stworzenie kompendium pomocnego w promocji języka polskiego w świecie) nie wykluczaja, ze względu na wiedzę, którą zawieraja, potraktowania ich także jako ważnych podręczników z zakresu dydaktyki polonistycznej w świecie. Oba pokazują nauczanie języka polskiego w sytuacji dokonującego się rozwoju i jego dalszych możliwych dróg. Jest faktem, że zasadniczym przedmiotem rozważań wspomnianych prac stała się różnorodnie funkcjonująca edukacja językowa, niemniej jednak w obu książkach pojawiają się także informacje związane z edukacją literacką i kulturowa. Bywa, że w rozważaniach termin nauczanie jezylka jest używany metonimicznie w stosunku do szeroko rozumianej edukacji polonistycznej, albowiem podejmowane zagadnienia dotyczą praktyk edukacyjnych (dydaktycznych), w których literatura i kultura albo stanowią poręczne narzędzie w nauczaniu języka, albo są odrębnym przedmiotem. Wydaje się, że refleksje na temat rozwoju glottodydaktyki polonistycznej (edukacji polonistycznej) zamknięte $\mathrm{w}$ przedstawionych opracowaniach warto uzupełnić dodatkowy- 
mi spostrzeżeniami dotyczącymi możliwych dróg przeobrażeń w ramach tej dyscypliny i aktywności dydaktycznej. Celem niniejszych uwag nie jest zatem rozwój edukacji polonistycznej, aczkolwiek takie dzieła jak np. opisywana ekspertyza kusza, aby na ich podstawie stworzyć model nauki w ujęciu diachronicznym. Jest natomiast ich zamiarem wskazanie przemian czy przeobrażeń, a może po prostu innowacji, jak chce Miodunka, tej dydaktyki ewokowanych przez nowe metodologie i wydarzenia globalne o światowym znaczeniu, które mogą inspirować naukę i dydaktykę. Są to przeobrażenia i przemiany powtórzmy słowa wstępu - albo dokonane, albo takie, które powinny zostać starannie przemyślane jako propozycje zmian w obrębie dyscypliny. Obszar ich zaistnienia jest różnorodny. Są to i metody nauczania, sposoby prowadzenia zajęć, relacje komunikacyjne, i treści programowe, i koncepcje podręczników oraz materiałów pomocniczych, wreszcie - cele prymarne i dodatkowe glottodydaktyki. Obejmuja obszary specyficzne dla glottodydaktyki polonistycznej oraz te, które ona dzieli z innymi naukami i nauczaniem jako subdyscyplina lub dyscyplina pokrewna. Mogą się one przejawiać różnorodnie - od modyfikacji po uzupełnienia i zmiany oraz rewizje w status quo dyscypliny. Trzeba także powiedzieć, że dokonują się one (lub już się dokonały) w naukach humanistycznych i w krajowej dydaktyce polonistycznej oraz dyscyplinach jej pokrewnych. Określić je można czterema słowami kluczami: zwrot metodologiczny i nowa humanistyka, ekologia, migracja i pandemia ${ }^{4}$.

$$
* * *
$$

Rozwojowi nauczania języka polskiego jako nierodzimego towarzyszył, co na swój sposób naturalne, rozwój form dydaktycznych komplementarnych

\footnotetext{
${ }^{4}$ Literatura poświęcona nowej humanistyce jest już obszerna, a dyscyplina w nowym kształcie weszła zapewne w fazę ,zajmowania pozycji i negocjowania autonomii” w naukach humanistycznych. Liczne są także prace poświęcone dydaktyce szkolnej na rzecz nowej humanistyki i te, w których migracja i ekologia są opisywane jako obszary determinujące kształtowanie się jej nowego oblicza. Źródłem wiedzy w obu przypadkach są m.in.: seria Nowa Humanistyka, numery monograficzne „Tekstów Drugich”, rozprawy pomieszczone w materiałach ostatnich Światowych Kongresów Polonistów (zwłaszcza ostatniego w postaci opracowania Polonistyka na poczatteu XXI wieku. Diagnozy, koncepije, perspektyny, Tambor red. 2018) oraz konferencji Stowarzyszenia „Bristol”. Prace podejmujące taką problematykę były publikowane w monograficznych numerach „Postscriptum Polonistycznego": 2012, nr 2 (Dydaktyka, glottodydaktyka - miejsca wspólne); 2015, nr 2 (Perspektymy glottodydaktyczne); 2018, nr 2 (Glottodydaktyka wśród drieci i mtodzieży wobec wyzwan wielo-, transkulturowości i ruchón migracyjnych); 2019, nr 2 (Migracje i ich konsekwencje).
} 
dla tego nauczania, a związanych z literaturą i kultura polska. Zaowocowało to powstaniem studiów polskich niejako alternatywnych wobec rodzimej polonistyki, ale pozafilologicznych w swej istocie oraz form edukacji literackiej i kulturowej cudzoziemców, co wraz z edukacją językową zaczęło tworzyć edukację polonistyczną cudzoziemców jako zorganizowaną formę dydaktyczną. Rozpięta pomiędzy dydaktyką i polonistyką w swej interdyscyplinarności korzysta ona z tego, czym żywią się wymienione dyscypliny, adaptując jednak idee na swój grunt. To, co najważniejsze, literatura i kultura jako obiekt namysłu i nauczania, są traktowane zarówno jako poręczne narzędzie w nauczaniu polszczyzny, jak również jako samodzielny, autonomiczny obiekt nauczania.

Zwrotem metodologicznym w naukach humanistycznych, nazwijmy go antystrukturalnym, wobec którego glottodydaktyka polonistyczna powinna się opowiedzieć, był na pewno przewrót, jaki dokonał się pod koniec XX wieku, albowiem on zapoczątkował nowe poststrukturalne widzenie języka, literatury i kultury, unieważniając, albo przynajmniej biorąc w nawias, strukturalne opisy i porządki świata. Ma on niezaprzeczalny wpływ na kształtowanie się m.in. polonistycznej edukacji literackiej.

Miałem okazję o tym pisać szerzej w artykule na poły postulatywnym, a dotyczącym koniecznych przemian w jednym $\mathrm{z}$ istotnych obszarów dydaktyki polonistycznej - w edukacji literackiej cudzoziemców (Cudak 2015). Zwracałem wówczas uwagę, że uwzględniając zmiany dokonujące się w metodologii, należałoby przewartościować między innymi charakter spotkań z literatura jako centralnego elementu tej edukacji zarówno z perspektywy nowych ujęć literatury i sposobów jej rozumienia, jak również z racji wynikającego z tych zmian nowego rozumienia lektury. Postulowałem, aby przemyśleć zasadność tworzenia osobnych kursów literatury i poszukiwania kanonów literackich w sytuacji, gdy - zdawało się - sama literatura traci swe istotne, wypracowane w historii funkcje społeczne, a kultura przestaje być literaturocentryczna. Proponowałem, by kursy te zastąpić spontanicznymi spotkaniami z dziełami literackimi, a kanony - budowaniem kolekcji literackich złożonych z utworów, których wartość wiąże się z globalnym odbiorem albo światowościa tekstu. Zwracałem uwagę, aby w przygotowaniu takich spotkań uwzględniać nowe nośniki literatury - piosenkę, np. w przypadku poezji śpiewanej i film, serial, czyli adaptację filmową w przypadku powieści. Sugerowałem rozszerzenie tych spotkań o rozmowy na temat współczesnych tęsknot poezji do zagubionych w rozwoju form liryki i melorecytacji, które maja swoje odzwierciedlenie choćby w poezji slamowej i ambitnej tekstowo piosence (hip- 
-hop, rap) oraz poświęcanie ich również popularnym wśród twórców i odbiorców formom non fiction poszerzającym granice współczesnej literatury. Wskazywałem, że zwrot suponuje, aby stricte literacki ogląd literatury jako arcydzielności języka zastąpić rozumieniem jej jako artefaktu kulturowego. Pisałem wreszcie, aby - jak chce Markowski (2001) - przejętą z edukacji szkolnej formę lektury-interpretacji i uczonego śledztwa, które prowadzi do powtarzania myśli o tekście dawno już podanej do wiadomości jako nakazana profesjonalna egzegeza, zastąpić formą spotkania, będącego „amatorskim użyciem tekstu”. Po latach widać, że jest to kierunek, w którym ewoluuje zarówno refleksja na temat edukacji literackiej, jak i praktyka glottodydaktyczna 5 .

$* * *$

Zwrot metodologiczny w naukach humanistycznych wyzwolił także tendencje, które doprowadziły do powstania „nowej humanistyki”. Aktualnie, kiedy ma ona za soba początki swojego rozwoju i przechodzi z okresu heroicznego ku apogeum, widać, że pojawiała się również w centrum zainteresowania krajowej dydaktyki polonistycznej. To, co stało się jej dorobkiem, powinno być także obszarem namysłu do wykorzystania przez glottodydaktykę polonistyczną. Myślę w tym przypadku o ideach, postulatach i programach, jakie są zamknięte np. w koncepcji humanistyki ekologicznej czy środowiskowej, a może już polonistycznej dydaktyki ekologicznej czy też dydaktyki dla klimatu. Ewokowane postawy, działania, zachowania stają się zasadniczym budulcem nowego modelu egzystencji i aktywności człowieka, a zadaniem, jakie dydaktyka stawia przed soba, jest wychowanie w tym właśnie duchu. Glottodydaktyka, ze względu na specyfikę nauczania, nie musi uznawać tych idei za wiodace w procesie edukacji, niemniej jednak powinna definiować swoje zadania w perspektywie proponowanych zmian.

Jak wiadomo, punktem wyjścia w tym namyśle jest przekonanie, że od 200-250 lat żyjemy w epoce geologicznej antropocenu, którą cechuje dominujący wpływ człowieka na ziemski ekosystem. Jego efektem jest globalne zagrożenie życia na Ziemi, a przygotowywana własnymi rękami apokalipsa może się nie wydarzyć, jeśli dokona się zbiorowa ekologiczna metanoja i na-

${ }^{5}$ Wskazać trzeba przede wszystkim prace T. Czerkies. 
rodzi się nowy homo ecologicus. Rolę tę powierza się między innymi naukom humanistycznym, a zatem i nowoczesnej dydaktyce biorącej współodpowiedzialność zbiorową za zaistniały stan rzeczy i podejmującej obowiązek zaradzenia temu ${ }^{6}$. Chodzi przede wszystkim o przemodelowanie świadomości zbiorowej i wytworzenie we współczesnym człowieku wrażliwości ekologicznej i empatii środowiskowej wobec innych form istnienia ziemskiego. Ważne staje się budowanie obrazu świata i form poznania (doświadczania), dla których istotne będą takie idee, jak partnerstwo, kooperacja, całość, etyka solidarności, natura jako wspólny dom i samoistna wartość życia roślin i zwierząt. Nowe, a może w ramach meatanoi - odnowione doświadczanie świata budowane na wspomnianych ideach jest możliwe, jeśli w przewartościowaniu będą nam pomagać nowe obrazy świata, które ewokują nie tylko poszerzenie czy wymianę leksyki, ale także przebudowę jej semantyki, nowe formy komunikacyjne, a także rewizjonistyczna lektura dotychczasowej literatury i kultury. A ponieważ problem jest tyleż globalny, ile lokalny, to musi być uwzględniony również w glottodydaktyce polonistycznej. To wymaga namysłu, dlatego też tylko na zasadzie spontanicznie tworzonego przykładu powiedziałbym, że chodzi (także) przynajmniej o dokooptowanie do sfer narzędzi i poznania w nauczaniu glottodydaktycznym tego, co poręcznie można nazwać środowiskiem (przyrodniczym) i - mniej poręcznie - naturą. Przedmiotem rozważań może się stać środowisko (natura) jako temat tekstów kultury oraz sposoby nadawania mu wymiaru krajobrazu i pejzażu jako działalności kulturowej, rodzaje literatury i kultury szczególnie predestynowane do nauczania w takiej perspektywie, to, co ekokrytyka nazywa zakorzenieniem czy uziemieniem literatury, konieczność przewartościowania frazeologii związanej ze zwierzętami oraz kulturowych alegoryzacji świata zwierzęcego (także w twórczości dla dzieci, z której chętnie czerpiemy) i ogólniej - przejrzenia zadomowionych wśród ludzi postaw wobec zwierząt. Oczywiście, należy zwrócić uwagę na tworzące się nowe horyzonty oraz nowe systemy symbiozy z przyrodą i wszelkim stworzeniem. Świat ekologiczny w swojej wielowymiarowości (od zagrożeń klimatycznych, kataklizmów, relacji wobec zwierząt i przyrody po śmieci, segregację i recycling) musi po prostu stać się jeśli nie preferencyjny, to na pewno uobecniony w programach, na zajęciach, w podręcznikach i w osobliwych dla siebie strukturach językowych i tekstowych polszczyzny oraz tekstach kultury, a także w tema-

$6 \mathrm{~W}$ referowaniu korzystam z klasycznych już opracowań na ten temat, m.in.: Bińczyk 2020; Nycz 2017; Czapliński 2017. Zob. także „Teksty Drugie” 2017 i Ślósarz 2018. 
tyce prowadzonych spotkań. A dydaktyka ekologiczna inspirowana przez humanistykę zaangażowaną musi stać się miejscem spotkań dydaktyki szkolnej i glottodydaktyki polonistycznej

$$
* * *
$$

Życie człowieka, jak nigdy dotąd, stało się życiem w ruchu, podróża, pokonywaniem czasu i przestrzeni, przemieszczaniem się. Formom nomadycznych globalnych błąkań towarzyszą zamierzone, celowe i zorganizowane podróże. „Biegun”, wędrowiec to nie tylko metafora współczesnego życia człowieka, ale także status ludzkości, czego wysublimowaną formą na przełomie XX i XXI wieku okazały się globalne ruchy migracyjne. Homo migrans stał się szczególnym przypadkiem homo viator. Jak nigdy dotąd z taką siłą ujawniły się fenomeny powiązane $z$ różnorodnymi formami przemieszczania się olbrzymich grup społecznych - ludzi uciekających przed wojennym zagrożeniem życia, poszukujących chleba i lepszych warunków egzystencji, pragnących zdobyć lepsza pracę i poprawić status rodziny. Do tych fenomenów należą między innymi sytuacje związane $z$ komunikacją międzykulturową $i$ wielokulturowościa, jak również konsekwencje - różnego rodzaju i typu - ewokowane w obszarze rozmaitych form migracji i strategii akulturacyjnych - zarówno integracji i asymilacji, jak i marginalizacji, i separacji. Nie trzeba dodawać, że fenomen spotkań ludzi różnych kultur nie jest obcy społeczności Polaków, posiada swoją rozległą historię nie tylko w postaci emigracji Polaków, ale także przyjmowania imigrantów na ziemie polskie, a aktualnie uobecnia się choćby w postaci problemu przygarniania uchodźców, ruchu migracyjnego ze Wschodu, zmasowanych wyjazdów zarobkowych Polaków do innych krajów Unii Europejskiej i częstych, zaplanowanych bądź wymuszonych, powrotów do kraju po kilku- czy kilkunastoletnim pobycie za granica.

Ów fenomen migracji uobecnia się pod wieloma postaciami i domaga się zainteresowania ze strony współczesnej nauki - z różnych powodów i ze

${ }^{7}$ Nie znalazłem prac, które wiązałyby edukację glottodydaktyczną z ideami humanistyki ekologicznej. Są natomiast prace podejmujące zagadnienie tworzenia (szkolnej) dydaktyki ekologicznej. Autorami wielu z nich są badaczki Interdyscyplinarnego Centrum Badań nad Edukacją Humanistyczną Uniwersytetu Śląskiego w Katowicach: Bernadeta Niesporek-Szamburska, Magdalena Ochwat, Małgorzata Dudek-Wójcik, Małgorzata Kita, Wioletta Hajduk-Gawron. 
względu na różne cele, wprasza się nie tylko jako obiekt refleksji, ale także jako sytuacje domagające się swoistego sterowania nimi i optymalizowania ich przebiegu. Rodzi to również szereg problemów, jakimi powinna zainteresować się swoista „dydaktyka migracyjna”. Jest tu również miejsce dla glottodydaktyki.

Można rzec, że i w tym przypadku zrobiono już sporo. Tak w zakresie zagadnień, w których Polska jest krajem przyjmującym, jak i wtedy, kiedy jest społecznością przyjmująca.

Zróżnicowana struktura migracyjna generuje sytuacje nauczania istotne dla dydaktyki oraz dla glottodydaktyki, a także dla statusu wyuczanego języka. Powoduje jednocześnie rozmycie opozycji podstawowej dla tego statusu: rodzime (ojczyste) - obce, w taki sposób, że nanosi na oba człony alternatywy dodatkowe zróżnicowania, biorąc pod uwagę m.in. doświadczenia transkulturowości uczących się. W refleksji dotyczącej sytuacji języka polskiego i szerzej - edukacji polonistycznej zaczęto wyodrębniać sytuacje nauczania/uczenia się, w których udział biorą starsze i młodsze osoby z kręgów migracji polskich i kręgów polonijnych, dla których język polski jest językiem drugim, odziedziczonym. Z kolei w charakterystyce języka polskiego jako obcego zaczęto wyodrębniać sytuacje, kiedy edukacja dokonuje się wśród cudzoziemców i dotyczy dzieci emigrantów, imigrantów i reemigrantów polskich edukowanych w polskich szkołach. Oczywiście, w ślad za podstawowymi rozpoznaniami idzie również konieczność stworzenia adekwatnych metod nauczania języka i wymodelowania edukacji kulturowej oraz projektowania ukierunkowanych form dydaktyki uzależnionych od sytuacji, w jakiej znajduje się uczeń i w jakiej samo nauczanie przebiega. Tu, w sposób widoczny, glottodydaktyka „obniża loty” i zainteresowana sytuacją młodego ucznia szkoły podstawowej i średniej staje na pograniczu z dydaktyka, zamazując wyrazistsze granice pomiędzy dyscyplinami. O konieczności podejmowania wspomnianych zagadnień i rozwiązywania implikowanych przez migracje problemów mówi m.in. Nauczanie i promocja jezyłka polskiego $w$ świecie, modelując te sytuacje, diagnozując je i formułując postulaty. Kierunek badań w tym zakresie wskazują także prace m.in. badaczy krakowskich czy katowickich zainteresowane różnorodnie doświadczaną wielokulturowością ucznia i edukacją uwzględniająca skomplikowane sytuacje komunikacji międzykulturowej ${ }^{8}$. Wytwarza się obszar zagadnień interdyscyplinarnych,

8 Tytułem przykładu warto wymienić opracowania A. Seretny upowszechniającej koncepcję języka odziedziczonego i E. Lipińskiej, która bada zróżnicowanie języka polonijnego, jak 
które są podejmowane w sposób zintegrowany przez dydaktykę szkolną i glottodydaktykę polonistyczną?

Najświeższą sytuacją zaistniałą na początku XXI w., która na pewno będzie mieć wpływ na przeobrażenia w zakresie nauczania języka polskiego jako obcego, jest pandemia spowodowana przez rozpowszechniający się od marca 2020 roku koronawirus. Wpływ ten będzie odczuwalny w edukacji polonistycznej, ale też w innych naukach humanistycznych.

Pandemia aktualnie podlega swoistej tabuizacji ${ }^{10}$. Wiele mówi się o niej jako o fakcie medycznym, niewiele zaś o tym, że mamy do czynienia z wydarzeniem, które jest zdolne wykreować nową rzeczywistość, nowy - w swoich podstawowych cechach i właściwościach - świat. Tworzone nowe realia traktuje się w dyskursie pandemicznym jako świat prowizoryczny, tymczasowy, awaryjny, który kiedyś przeminie, a wówczas ludzkość powróci do rzeczywistości opuszczonej na czas epidemii. Metafora „poczekalni” zaczerpnięta z Díumy Camusa, a przypomniana przez Ryszarda Koziołka11, znakomicie oddaje w swoim sensie to, jak przeżywamy, odczuwamy i to, jak

również prace W. Hajduk-Gawron. Warto odnotować, że już w 2012 r. ukazał się numer „Postscriptum Polonistycznego” wskazujący „miejsca wspólne” dydaktyki i glottodydaktyki polonistycznej i zawierajacy referowane problemy, w 2018 r. numer 2. zawierający materiały na temat glottodydaktyki wśród dzieci i młodzieży wobec wyzwań wielo-, transkulturowości i ruchów migracyjnych, a w 2019 r. numer 2. tego pisma został poświęcony „migracjom i ich konsekwencjom". Tu podjęto zagadnienia dydaktyki ukierunkowanej na dzieci wychowujące się w środowisku obcojęzycznym, uczniów z doświadczeniem migracyjnym, uczniów cudzoziemskich w polskim systemie edukacyjnym.

${ }^{9}$ Oczywiście, nie można pominać w tym przypadku podstawowej sytuacji dydaktycznej nauczania języka polskiego jako obcego, zwracając uwagę na tak ważne sprawy, jak prezentacja środowiska w programach treściowych, tematyce zajęć i w podręcznikowych lekcjach. Jest ono dotychczas bardzo familiocentryczne i najczęściej hermetrycznie sprowadzane do klasycznego modelu rodziny.

${ }^{10}$ Symptomatyczna jest sytuacja, że środki masowego przekazu wycofały się w tym przypadku z poetyki budowania przekazu „ociekającego krwia”" i że rzadko spotykanym na wizji (choć niestety znanym z życia) jest obraz stojących na parkingach czy boiskach niekiedy setek trumien osób pokonanych przez COVID-19, zmarlych i chowanych bez pożegnania z bliskimi.

${ }^{11}$ Myślę o wykładzie Ryszarda Koziołka O potrzebie fikciji wygłoszonym na inauguracji XXX letniej szkoły języka, literatury i kultury polskiej organizowanej przez SJiKP UŚ, zaś w roku jubileuszowym po raz pierwszy w sposób zdalny. 
myślimy o otaczającej nas aktualnej rzeczywistości. Tymczasem wśród naukowców coraz częściej słyszy się przekonanie, że świat zaistniały w czasie pandemii nie przeminie i że już nic nie będzie takie samo jak przedtem. Paradoksalnym potwierdzeniem prawdziwości tych sądów zdaje się wyraz społecznej niewiary $\mathrm{w}$ te twierdzenia, uwidaczniany $\mathrm{w}$ demonstracyjnym lekceważeniu zakazów i obostrzeń, czego symbolem jest „bunt wobec maseczek” będących najwidoczniejszym znakiem nowego, które stało się powszechne i codzienne.

Coraz częściej próbujemy ten tworzący się nowy świat opisać, dokonujemy detabuizacji i zaczynamy analizować nową, otaczającą nas rzeczywistość, próbujemy formułować modele powstającego świata oraz kodyfikować postawy, działania i zachowania, które określają nasze życie codzienne.

Świat pandemiczny, świat zarazy to jeden z obszarów katastrof i kataklizmów. Ma swoje ujęcia w tekstach kultury funkcjonujących jako bezpośrednie lub pośrednie świadectwa kataklizmów pandemicznych, które nas już nawiedziły, w dyskursie maladycznym. Warto przypomnieć choćby Dekameron, Drienniki roku zarazy czy klasyczny „dokument”, jakim jest Dżuma. Trzeba jednak pamiętać, że są one świadectwami świata, w którym perspektywa pandemiczna jest budowana właśnie na metaforze poczekalni, a u jej podstaw leży nadzieja na odwrócenie losów. My musimy wypracowywać wizję, w której świat jest innym domem niż był, aczkolwiek tworzenie tego obrazu trzeba zaczać od rozpoznania sytuacji. To się już chyba dokonuje, podobnie jak w sytuacji zagrożenia ekologicznego czy przewartościowań społecznych struktur, więzi i relacji w przypadku masowej migracji. Kiedy milczy (jeszcze?) na ten temat literatura, szczególnie do tego predestynowana, kiedy milczy (jeszcze?) filozofia, działać musimy sami. Wiemy już, że pandemia w sposób śmiertelny zagroziła (także) więziom społecznym i ograniczyła życie wspólnot, że proponuje jako niezbywalną alternatywę rozproszenie, dezintegrację, świat zamknięty w domach i osamotnienie (nie - prywatność), że dotyka ograniczaniem, unieruchamianiem i zawieszaniem komunikacji bezpośredniej na rzecz komunikacji zdalnej. Skoro nie ma na razie materiałów, które mogłyby nam pomóc w takiej „zaktualizowanej” edukacji, warto przynajmniej sięgnąc do tego, co jest. Dobrym przykładem, znowu wybranym nieco na chybił trafil, może być nauczanie leksyki związanej z choroba i tworzącej specyficzne obrazy świata. Myślę w tym przypadku zarówno o sposobach metaforyzacji choroby, zagrożenia życia, śmiertelnego niebezpieczeństwa, jak też o chorobie jako sposobie metaforyzacji życia ${ }^{12}$. Istotne stają się

12 Pojawiają się np. pierwsze neologizmy. Test na obecność wirusa polega na wymazywaniu, sposobem ochrony przed chorobami wirusowymi jest wyszczepianie, nosiciel wirusa to nie jak niegdyś zarażony, ale zakażony. Notabene trzeba odnotować i to, że podręczniki do nauki ję- 
elementy doświadczania czasu i przestrzeni, które dyktuje walka z wirusem i które powoli zakorzeniają się w świecie (kwarantanna, dystans społeczny, przestrzeń publiczna, reżim sanitarny, witanie się przez dotykanie łokciem lub skinienie głowa). Warto zwrócić uwagę na modyfikację kontaktów i więzi rodzinnych, ale także na nowe elementy lub nowe funkcje rzeczy już istniejących w naszym otoczeniu. Myślę o ucodziennianiu się medycznego kombinezonu ochronnego, ale przede wszystkim maseczki, która dla dzieci staje się zwykłym, powszechnym i naturalnym (?) wyposażeniem odzieżowym, a dla starszych elementem stroju, który zaczyna podlegać prawom mody.

Innym istotnym zjawiskiem, które paradoksalnie można nazwać prezentem, jaki ofiarowała nam pandemia, jest upowszechnianie się modelu komunikacji na odległość, który w czasie zarazy zyskał status modelu preferowanego, skutecznego w określonych przez pandemię warunkach społeczno-ekonomicznych, modelu komunikacji sieciowej i online. Chodzi zwłaszcza o przydatność komunikacji zdalnej w edukacji, przede wszystkim zaś w edukacji cudzoziemców. Do tej pory bowiem formy komunikacji zdalnej i e-nauczanie zwykło się traktować jako uzupełniające i komplementarne. Komunikacja bezpośrednia w nauczaniu cudzoziemców była preferowana ze względu na specyficzną sytuację uczącego się oraz cechy i właściwości kontaktu bezpośredniego. Racja była w tradycyjnym przekonaniu, że języka i kultury danego narodu uczy się najlepiej „na miejscu”, wśród ich użytkowników i w wyuczanej przestrzeni cywilizacyjno-kulturowej. Wskazywano również w takich sytuacjach plusy komunikowania audytorialnego, które cechuje wspólnota tu i teraz nadawcy i odbiorcy. Trudno się z tym nie zgodzić. Należy jednak pamiętać, że wprowadzane przecież do edukacji formy elektroniczne - motywowane skądinąd tym, że są one na swój sposób dostosowane do sposobów postrzegania i poznawania świata zwłaszcza przez młode pokolenia traktowane były jednak po macoszemu. Przyzwyczajeni do komunikacji tradycyjnej i przekonani o wyższości edukacji bezpośredniej, konstruowaliśmy prezentacje elektroniczne, ignorując ich specyficzną poetykę, a powielając konwencje naszych tradycyjnych papierowych ściagawek i mając przy tym smutna świadomość, że nie przynosi to żadnego pożytku. Dowiedzieliśmy się o tym boleśnie, kiedy w sposób elektroniczny przyszło nam kontaktować się z uczniami i studentami „na poważnie”, w sytuacji kryzysowej. To bankructwo idei wymusiło konieczność, motywowaną nie tylko etycznie, auten-

zyka polskiego jako obcego przygotowują językowo - i to dość pobieżnie - do mówienia na temat chorób, które są sezonowe i przydarzają się, jako powszechne, raczej standardowo. Sytuacji zachorowań poważnych, zagrożeń zdrowia i życia w zasadzie nie ma w tematyce zajęć. 
tycznego sięgnięcia po formy komunikowania elektronicznego, kiedy e-komunikacja ma status podstawowego sposobu porozumienia się we współczesnym świecie, zatem i w edukacji. Glottodydaktyka, podobnie jak inne dydaktyki, musi uwzględnić taką sytuację, tworząc rejestry sposobów skutecznego wykorzystania komunikacji zdalnej w nauczaniu. Trzeba jednak pamiętać, aby o komunikacji pośredniej oraz o e-nauczaniu myśleć nie jako o formach awaryjnych i zastępczych, nie jako o elemencie nauczania hybrydowego, ale jako o sposobach alternatywnych i autonomicznych, „oryginalnych”, niezastępujących i niezastępowalnych, w których - dodajmy - rzeczywistość wirtualna skutecznie konkuruje z realną. Można jednak rzec i tak, że dla nauczania osób, których „,naturalne” „tu i teraz” jest inne niż uczącego, ta istotna dla statusu cudzoziemca odległość i dystans, dalekość jest w tym przypadku motywująca do uwzględnienia sytuacji edukowania zdalnego. Pozbawieni nieocenionej realności i bezpośredniości kontaktu ucznia z wyuczaną materią, zyskujemy jednak inne profity związane na przykład z dostępnością technologiczną edukacji na odległość (wystarczy mieć komputer i zainstalowany program) i z jej dostępnością ekonomiczną. Składniki nauczania zdalnego takie jak duplikaty świata pojawiające się w prezentacjach czy wirtualny nauczyciel uobecniony w elektronicznej klasie, a oddalony w realnym czasie nawet o dobę i tysiące kilometrów, sa elementami doświadczanymi i często naturalnymi w postrzeganiu i poznawaniu świata, jeśli pamiętamy, że źródłem wiedzy o świecie już dawno stała się Wikipedia. Dotyczy to sytuacji cudzoziemca, dla którego właśnie dystans i oddalenie są wyznacznikami obcości, ale także po prostu przedstawicieli młodszych pokoleń.

Glottodydaktyka polonistyczna ma swoje osiagnięcia, jeśli chodzi o wykorzystanie, także zdalne, komputera i sieci do nauczania języka polskiego jako obcego $^{13}$, jednakże przeobrażenia wynikające ze współczesnych sytuacji wymagałyby przemian jakościowych. Jest to możliwe, kiedy technologia komunikowania zdaje się minimalizować wirtualność wyuczanej rzeczywistości i świata, w którym się uczymy tak, że na zasadzie zdalnej komunikacyjnej imitacji można skonstruować całą letnią szkołę języka, literatury i kultury polskiej, łącznie z takimi wypracowanymi formami jak Wieczór Narodów, na którym cudzoziemscy studenci prezentują kulturę i obyczaje swoich narodów. A przecież tak się już wydarzyło ostatniego lata.

13 Odnotowuje je również W.T. Miodunka, wskazując prace glottodydaktyków katowickich i R. Dębskiego. Przy okazji warto przypomnieć, że w czasach PRL-u telewizja uczyła języków obcych na odległość. 


\section{Bibliografia}

Baran M., 2015, Dydaktyka kultury a podejście ukierunkowane na działanie w nauczaniu jezyka polskiego jako obcego, „Postscriptum Polonistyczne”, nr 2.

Bińczyk E., 2020, Epoka człowieka. Retoryka i marazm antropocenu, Warszawa.

Cudak R., 2012, Edukacja literacka cudzoziemcón w sytuacji przemian, „Postscriptum Polonistyczne", nr 2.

Czapliński P., red., Nowa humanistyka. Zajmowanie posycji, negowanie autonomii, Warszawa.

Gębal P.E., 2018, Rozwój teorii i praktyki nauczania jezyyka polskiego jako obcego $i$ drugiego w latach 1950-2015. Uwagi na marginesie „Glottodydaktyki polonistycznej” W.T. Miodunki, ,Język Polski”, z. 2.

Markowski M.P., 2001, Interpretacja i literatura, „Teksty Drugie”, nr 5.

Miodunka W.T., 2004, Kompetencja socjokulturowa w nauczaniu jezyka polskiego jako obcego. Zarys programu nauczania, w: tegoż, red.: Kultura w nauczaniu jezylka polskiego obcego, Kraków.

Miodunka W.T., 2016, Glottodydaktyka polonistyczna. Pochodzenie - stan obecny - perspektywy, Kraków.

Miodunka W.T., Tambor J. i in., 2018, Nauczanie i promocja jezylka polskiego w świecie. Diagnoza stan - perspektywy, Katowice.

Nycz R., 2017, Kultura jako czasownik. Sondowanie nowej bumanistyki, Warszawa.

„Postscriptum Polonistyczne” 2012, nr 2.

„Postscriptum Polonistyczne” 2015, nr 2.

„Postscriptum Polonistyczne” 2018, nr 2.

„Postscriptum Polonistyczne” 2019, nr 2.

Ślósarz A., 2018, Dydaktyka „nowej bumanistyki”: szanse i nieuniknione zagrożenia, w: Cudak R., Pospiszil K., red., Polonistyka na poczqtku XXI wieku. Diagnozy, koncepcje, perspektyny, t. 1, Literatura polska i perspektywy nowej humanistyki, Katowice.

Tambor A., 2018, O ekspertyzie nt. promocii i uczenia jesylea polskiego w śniecie, „Postscriptum Polonistyczne", nr 2.

Tambor J., red., 2018, Polonistyka na poczqtku XXI wieku. Diagnozy, koncepcje, perspektywy, t. 1-6, Katowice.

„Teksty Drugie” 2017, nr 1.

Zarzycka G., 2017, Glottodydaktyka polonistyczna w procesie rozwoju. Rozważania na marginesie monografii Władystawa T. Miodunki, „Poradnik Językowy”, z. 8.

Zarzycka G., 2019, Recenzja pracy: W. Miodunka, J. Tambor, A. Achtelik, R. Cudak, D. Krzyżyk, J. Mazur, T. Zgótka, wsp. M. Smereczniak, K. Graboń, „Nauczanie i promocja jezyka polskiego w świecie. Diagnoza - stan - perspektymy”, Katowice 2018, „Poradnik Językowy”, z. 6.

Cudak Romuald - dr hab. prof., Instytut Literaturoznawstwa, Uniwersytet Śląski w Katowicach, Katowice, Polska.

Redaktor naczelny „Postscriptum Polonistycznego". Autor licznych publikacji z zakresu literaturoznawstwa (poezja polska XX w., genologia literacka, recepcja literatury) i glottodydaktyki, m.in.: Czytając Białoszewskiego (Katowice 1999), Świetopełna trześć dziwosłów: interpretacje wierszy i szkice o współczesnej poezji polskiej (Katowice 1999), 
Inne bajki. W kręgu liryki Rafała Wojaczka (Katowice 2004), Recepcja literatury jako wyzwanie rzucone polonistyce literackiej? (2010), Edukacja literacka na kursach języka polskiego jako obcego (Katowice 2010), Światowość jako kategoria w badaniach nad recepcją literatury (Katowice 2013), Gatunek literacki i granice. Rozważania pograniczne (Katowice 2015). Redaktor i współredaktor wielu tomów zbiorowych i monografii, m.in.: Inne optyki (wspólnie z J. Tambor, Katowice 2002), Polska genologia literacka (Katowice 2007), seria Literatura Polska w Świecie (Katowice 2006-2016), seria Czytaj po Polsku (wspólnie z J. Tambor, W. Hajduk-Gawron, Katowice 2003-2016).

Kontakt: romuald.cudak@us.edu.pl 